IZA DP No. 8026

Shrinking Regions in a Shrinking Country: The Geography of Population Decline in Lithuania 2001-2011

Rūta Ubarevičienè

Maarten van Ham

Donatas Burneika

March 2014 


\title{
Shrinking Regions in a Shrinking Country: The Geography of Population Decline in Lithuania 2001-2011
}

\author{
Rūta Ubarevičienè \\ Lithuanian Social Research Centre \\ and Delft University of Technology \\ Maarten van Ham \\ Delft University of Technology \\ and IZA \\ Donatas Burneika \\ Lithuanian Social Research Centre
}

Discussion Paper No. 8026

March 2014

\author{
IZA \\ P.O. Box 7240 \\ 53072 Bonn \\ Germany \\ Phone: +49-228-3894-0 \\ Fax: +49-228-3894-180 \\ E-mail: iza@iza.org
}

\begin{abstract}
Any opinions expressed here are those of the author(s) and not those of IZA. Research published in this series may include views on policy, but the institute itself takes no institutional policy positions. The IZA research network is committed to the IZA Guiding Principles of Research Integrity.

The Institute for the Study of Labor (IZA) in Bonn is a local and virtual international research center and a place of communication between science, politics and business. IZA is an independent nonprofit organization supported by Deutsche Post Foundation. The center is associated with the University of Bonn and offers a stimulating research environment through its international network, workshops and conferences, data service, project support, research visits and doctoral program. IZA engages in (i) original and internationally competitive research in all fields of labor economics, (ii) development of policy concepts, and (iii) dissemination of research results and concepts to the interested public.
\end{abstract}

IZA Discussion Papers often represent preliminary work and are circulated to encourage discussion. Citation of such a paper should account for its provisional character. A revised version may be available directly from the author. 


\section{ABSTRACT \\ Shrinking Regions in a Shrinking Country: The Geography of Population Decline in Lithuania 2001-2011}

Shrinking populations have been gaining increasing attention, especially in post-socialist East and Central European countries. While most studies focus on the population decline of capital cities and their regions, much less is known about the spatial dimension of population decline on the national level. Lithuania is one of the countries which have experienced very high levels of population decline in the last decades. This study uses Lithuanian Census data from the years 2001 and 2011 to get insight into the geography of population change for the whole country. The results show a sharp population decline in Lithuania of $17.2 \%$ between 1989 and 2011, with the decrease being more intense during the second decade of the period. The population dropped in most areas, including the main cities, but increased in the regions surrounding these cities. The predictive models show a clear geographical dimension of population decline, but also reveal that population composition and investments play a role in the process of decline.

JEL Classification: J11, J61, P20, R23

Keywords: population decline, shrinking regions, post-socialist transition, suburbanization, Lithuania

Corresponding author:

Rūta Ubarevičienè

OTB - Research for the Built Environment

Faculty of Architecture and the Built Environment

Delft University of Technology

PO Box 5030

2600 GA Delft

The Netherlands

E-mail: ruta.ubareviciene@gmail.com 


\section{INTRODUCTION}

Recently, there has been a wide interest in shrinking cities and regions ${ }^{1}$ all over the world. Population decline has consequences for the economic base, labour market, housing market, and the social and technical infrastructures of regions. These consequences are especially severe in the post-socialist states of Central and Eastern Europe (CEE), which experienced some of the highest levels of population loss in the world during the last decades (Haase, 2013a; Hasse, 2013b; Hospers 2012; United Nations, 2013). This loss was conditioned by the profound political, economic and social transformations related to the demise of the Soviet Union at the end of the Nineteen Nineties. The deep economic recession, belated deindustrialization, decline in fertility rates and massive (job-seeking) out-migration, all resulted in a significant population loss in the CEE countries.

Lithuania is one of the leaders in terms of the population decline in the post-socialist region. According to Census data, in the period between 1989 and 2011 the country has lost $17,2 \%$ of its population. The actual figure is likely to be even higher because a lot of emigrants do not register when leaving the country (Civinskas et al., 2011). The process of population change is unevenly distributed throughout Lithuania: population decline at the level of municipalities ranges from only a few per cent to 34\% over the period of 1989-2011. In a few major cities the population dropped with $20-25 \%$, and there are villages that lost over $50 \%$ of their population. Although the population of the country as a whole is shrinking, there are also areas which have gained population. This applies mainly to the regions surrounding the major cities. The spatial variations in population change suggest that certain territorial characteristics influence the process of decline.

Although the topic of shrinkage receives increasing attention in the international literature, most attention is paid to specific cities or regions. Therefore little is known about the spatial dimensions of population change at the national level. Those studies which take a more national perspective (e.g., Cawley, 1994; Haartsen and Venhorst, 2009; Kupiszewski, Durham and Rees, 1998; Müller and Siedentop, 2004; Panagopoulos and Barreira, 2012; Wiechmann and Pallagst, 2012), usually limit analysis to certain aspects of decline, and do not analyse a broad set of territorial characteristics influencing spatially uneven population change. In this paper we argue that in order to understand population change and the underlying processes, a national level perspective should be employed.

The aim of this paper is to get more insight into the geography of population change in Lithuania and to increase our understanding of the factors which contribute to population change. We want to know to what extent population change varies between different regions, and how we can understand this variation. The main question posed in this paper is to what extent the spatial pattern of population change can be explained by locational factors (urbanrural distinction), and what are the underlying factors playing a role in this process in Lithuania. This study uses Lithuanian Census data from 2001 and 2011. The spatial level of seniünija is used for the analysis, which is the lowest statistical unit available in Census data. Linear regression analyses were used to model population change of areas from a set of variables, including geographic, social, demographic, and economic characteristics.

\footnotetext{
${ }^{1}$ In this paper we use term 'shrinkage' to indicate the process of a considerable and constant population loss. The term is also used to indicate employment decline or economic downturn (Hoekveld, 2012; Reckien and Martinez-Fernandez 2011). We use terms 'shrinkage' and 'population decline' interchangeably in this paper.
} 


\section{LITERATURE REVIEW ON POPULATION DECLINE}

Haase et al. (2013a) argue that 'the causes of shrinkage are as varied as they are numerous'. Population decline has proved to be a complex and multi-faceted phenomenon, which is highly dependent on political, economic and social conditions, it is therefore inconsistent and usually difficult to predict. Although shrinkage is now under a broad public and academic debate, it is a relatively new phenomenon in the contemporary western world. There is no theory of decline or clear and accepted definitions of 'shrinkage' and 'population decline' (Hoekveld, 2012). Moreover, planning for decline seldom appears on the agendas of politicians and urban planners, as growth orientated paradigms are still dominant (Müller and Siedentop, 2004).

Different spatial scales of shrinkage can be distinguished. Population decline can occur in a single city, a region, or even a whole country. Despite the fact that this decline is often a result of more than one cause, the most typical example of a shrinking city is the one in which industry is declining, leading to employment decline and population loss. High reliance upon a single declining industrial sector, combined with a failure to keep up with technological progress and a growing importance of the tertiary sectors, became a burden for many cities in the United States and Western Europe (Beauregard, 2013; Martinez-Fernandez et al., 2012; Rappaport, 2003; Wiechmann and Pallagst, 2012). Population decline at the regional level can also be found in large industrial areas in developed countries (Hudson, 2005; Polèse and Shearmur, 2006; Rumpel et al., 2010), but is also widespread in rural and peripheral areas (Cawley, 1994; Collantes et al., 2013; Jamieson, 2000; Niedomysl and Amcoff, 2011; Thissen et al., 2010; Westlund and Pichler, 2012). Rural decline is mainly caused by rural-urban migration of young people. A much more complex and extreme case of decline is when the population of a whole country shrinks. During the last decades, the sharpest population decline on the national scale occurred in the post-socialist countries of Central and Eastern Europe (CEE). This decline was caused by profound political system reforms, which resulted in significant social and economic changes in this region. While these are extreme cases, according to the projections of the United Nations, many of the developed countries might face population stagnation or decline in the coming decades (United Nations, 2013).

There are two main demographic trends associated with population decline: the first is natural decline, where more people die than are born; and the second is negative net migration, where more people leave than arrive. These two trends are closely related and may even accelerate each other. Since the spatial variations in births and deaths are generally only small (at least on the national level), most population change can usually be attributed primarily to net migration (Boyle, Halfacree and Robinson, 1998: page 45; Martí-Henneberg, 2005). A dominant approach towards understanding flows of people is based on neo-classical economic theory (Abreu, 2012; Arango, 2000; Lewis, 1954; Sjaastad, 1962; Stark and Bloom, 1985). This theory states that labour migration is the result of uneven geographical distribution of labour and capital, and that labour migration is mostly motivated by economic reasons measured by difference in wage levels. Therefore people generally flow from highunemployment to low-unemployment regions, and from low-wage to high-wage regions. In the neo-classical view, labour migration should eventually lead to a new (spatial) equilibrium of wages (Sjaastad, 1962).

Despite the success of the neo-classical economic model, it has been questioned on a number of counts. It is being noted that economic motives and rational decisions are not the only concerns of migrants. As stated by Blau and Duncan (1967) 'Men do not flow from places of poor to places of good opportunity with the ease of water'. Institutional (political) constraints, personal characteristics, migration networks (prior links between countries or 
individuals), stage in the family life-cycle and other factors are no less influential in determining mobility or immobility. Migration is therefore multi-layered and very complex in its nature. Different aspects of this complexity are being explained by deterministic, humanistic and biographical approaches (Ní Laoire, 2000). The alternative migration theories (e.g., The new economics of labour migration, Dual labour market theory, World system theory) assert that migration usually reinforces the inequality, instead of leading to its reduction (Abreu, 2012; Arango, 2000). Therefore, the differentiation between the migration origin and destination regions (and countries) appears to result in the concentration of people and economic resources in some places and to a decline in other places.

One of the biggest sources of migrants in contemporary Western Europe are the postsocialist countries. The reforms in the 1990s opened the borders and lifted restrictions on mobility, causing a massive outflow of people from these countries. Since the movement of people was highly regulated during Soviet times, even within the national borders, the political reforms liberated residential mobility and enabled people to emigrate. The opening of the borders resulted in an increasing migration flows from the post-socialist countries, partly fuelled by an economic recession and high levels of unemployment in these countries. The emigration especially speeded up after the Eastern enlargements of the EU in 2004 and 2007 when many CEE countries became a legal part of the EU and therefore residents could easily exploit better job opportunities in Western Europe (Kahanec, Zaiceva and Zimmermann, 2010).

High levels of out-migration are often followed by side effects such as an ageing population and lower birth rates in the 'losing' regions. This is because mainly young people move away and the ageing population is left behind. The initial migrant stream may encourage a second stream, when first migrants are followed by family and friends: this process is called 'chain migration', facilitated by a migration network (Boyle, Halfacree and Robinson, 1998: page 36). Another side effect of out-migration is so-called 'brain drain', when higher educated people move away (Favell, 2008; Kazlauskienè and Rinkevičius, 2006; Kelo and Wächter 2006). All of these effects are rather common in the CEE countries, and in many of these countries, the population decline is not limited to a decline in certain regions or cities, but affects whole countries. The underlying process is one of 'cumulative causation' (first developed by Myrdal, 1957), which means that once a negative development in an area has started, it is reinforced and thus leads to cumulative effects that make the situation even worse.

There may be many factors resulting in a spatially uneven population change on the national level. Notwithstanding that studies which investigate population decline at a national level are relatively rare, most studies only focus on specific factors determining population change. For example, there is research which mainly emphasizes geographical factors. The relationship between population change and size of place (in terms of population) has been explored by Cawley (1994). It was found that high rates of population decline positively correlates with the small size of places. Other authors have found relationships between population change and population density (Kupiszewski, Durham and Rees, 1998). The impact of the distance to cities and selected urban centers on the spatial pattern of population change was analyzed by Niedomysl and Amcoff (2011) and Westlund and Pichler (2012). These studies showed that peripheral countryside areas showed the biggest losses of the population, while metropolitan-adjacent areas experienced expansion. A series of studies pointed out that the surrounding areas of the major cities have the highest potential for population growth and in many countries, especially in CEE countries, these are the only areas gaining population nowadays (Borén and Gentile, 2007; Gentile, Tammaru and van Kempen, 2012; Nuissl and Rink, 2005; Schmidt, 2011; Sýkora and Ouředníček, 2007; Ubarevičienė, Burneika and Kriaučiūnas, 2011). Apart from the locational factors, many 
authors found a relationship between population change and various socio-economic characteristics of regions and cities. Age structure of the population is one of the most widely discussed factors which influences uneven population change. The age structure reflects the potential of the labor market and the reproductive capabilities of the population. Selective migration of specific age groups often results in an aging rural population and intense population decline (Burholt and Dobbs, 2012; Walford and Kurek, 2008). Meanwhile, familydriven suburbanization directed towards the peripheral areas outside the main cities leads to a younger age structure in these areas (Kroll and Kabisch, 2012). Younger age groups are also more frequently found in inner city areas, which are more viable in terms of economic and cultural life. In line with the neo-classical economic model, many authors emphasize that job and educational opportunities are the most important drivers of migration (Ní Laoire, 2000; Stockdale, 2004). Among the factors identified are average incomes, educational level of the population, size of labor market, rate of unemployment, number of enterprises per capita and level of foreign investments (Niedomysl, 2008; Schmidt, 2011; Tammaru and Sjöberg, 1999; Westlund and Pichler, 2012).

\section{POPULATION DECLINE IN THE POST-SOCIALIST COUNTRIES}

The massive population decline in the Central and Eastern European (CEE) countries can only be understood within the historical contexts of these countries. From 1945/50 to 1989/91 2 CEE countries were under communist Soviet regime and subject to a command economy model, which was based on the principles of central planning. The countries were isolated from the rest of Europe, with the Iron Curtain as the symbol of the ideological conflict between communism and capitalism. The communist states had very limited relations with the outside world and for most people it was impossible to cross the Iron Curtain. Population movement was also regulated between the communist states and even within the national borders. The communist regime has a strong influence on the spatial distribution of human and economic resources. According to Gentile and colleagues (2012: page 292) there was an intention to 'annihilate social, economic and regional differences and inequalities, effectively pushing for complete social, economic and spatial homogenization over time'. The communist planning doctrine even extended to controlling the size and hierarchy of cities and aimed at a more even spread of population, without having a dominant city (Bertaud and Renaud, 1997). Even though spatial planning was quite successful, countervailing forces and the reality of the urbanization process did not allow urban planning to achieve this ultimate goal (Bater, 1980; Huzinec, 1978). Some cities were growing much faster than was expected and spatial as well as social disparities remained (Musil, 2005). Although there were variations between CEE countries in terms of the adaptation of communist ideologies, the communist period had a strong impact on the socio-spatial organization of these countries and resulted in very different development paths compared to Western European countries.

The collapse of the communist regime in 1989/91 resulted in a new stage of development of the post-communist region (Musil, 1993; Sailer-Fliege, 1999; Smith and Timár, 2010; Sýkora, 1999). One of the major direct effects of the collapse, which accompanied the political, economic and social transformations, was a strong population decline, which began soon after the reforms started. Both, natural decline and negative netmigration contributed to the population loss. While emigration was fostered by the economic recession in the CEE countries and the new possibilities to search for better opportunities (job, education, quality of life, etc.) abroad, the natural decline was prompted not only by the

\footnotetext{
${ }^{2}$ The period of the socialism lasted differently in different CEE countries.
} 
transitions itself, but also by the sudden impact of the second demographic transition. The population decline appeared to be so sudden that some demographers have named it the 'demographic shock’ (Eberstadt, 1994; Rychtaříková, 1999; Sobotka, Zeman and Kantorova, 2003; Steinführer and Haase, 2007: page 259). It is interesting that the population loss in most of the CEE countries was accelerating over time, and it was considerably higher in the second decade of the transition period than in the first one. In many countries it can be explained by an increase in (job-related) emigration, which was enhanced after the accession of many CEE countries to the EU (Kahanec, Zaiceva and Zimmermann, 2010). The abolition of political, economic, social, cultural and psychological barriers and widening social networks abroad, contributed to the increasing emigration over time. The fact that younger people are overrepresented among those who left will result in further natural population decline as the population ages while fertility drops.

The population decline within CEE countries is not evenly spread. Personal and economic motives of individuals have replaced the communist planning doctrine (e.g. people used to live and work in the places where they got assignments), and are now the most important factor influencing population change. Despite the general population decline in CEE countries, there is an increasing concentration of people in the major city-regions since 1990s (Borén and Gentile, 2007; Nuissl and Rink, 2005; Sýkora and Ouředníček, 2007), although inner cities themselves still face a declining population (Steinführer and Haase, 2007). Rural regions have seen the most extreme population decline, which was reinforced by the dropping importance of agriculture, which was always prioritized under the communist regime (Enyedi, 1998; Leetmaa and Tammaru, 2007; Tammaru, 2001).

The combined effects of major economic, social, demographic and political transitions in the last 2 decades, have resulted in large scale emigration and natural population decline, which caused the socio-spatial landscape of CEE countries to change in a fast and dramatic way, not seen in any of the Western European countries (Smith and Timár, 2010; Stryjakiewicz, Ciesiółka and Jaroszewska, 2012).

\section{POST-SOCIALIST TRANSITION IN LITHUANIA}

The transition period was more challenging for the Baltic States than for the remaining CEE countries. Lithuania, Latvia and Estonia were a legal part of the Soviet Union during 1940$1990 / 1991^{3}$, therefore the Soviet principles of central planning were imposed more consistently here (Aberg, 2005; Borén and Gentile, 2007). From being one of the most affluent and prosperous regions of the Soviet Union, the Baltic countries became part of the poor periphery of the European Union. The Baltic States are now losing their population at one of the highest rates in the world (Berzins and Zvidrins, 2011). The trends of the sociospatial developments are similar between the three countries, where decline of the rural areas and growth and spread of the metropolitan areas are the main features (Cirtautas, 2013; Krupickaite, 2003). On the other hand, the transition period appeared to be more challenging for Lithuania. This was due to the fact that the unified settlement planning was implemented on a greater extent in Lithuania compared to the other Baltic States.

This planning was based on strengthening the development of regional centres and reducing the dominance of large cities (Bater, 1980; Sýkora and Čermák, 1998; Šešelgis, 1996). In Lithuania this meant that part of the potential growth of the few larger cities was distributed to other regions of the country. A uniform and highly hierarchical settlement system with equally distributed human and economic resources was developed during the

\footnotetext{
${ }^{3}$ Lithuania, Latvia and Estonia were incorporated into the Soviet Union under the pact of the MolotovRibbentrop in 1940. Lithuania gained independence in 1990 and Latvia and Estonia in 1991.
} 
Soviet times. In 1989, the capital city of Vilnius inhabited $15,7 \%$ of the country population, and had only $27 \%$ more population than the second largest city in the country. Meantime, Latvia and Estonia had highly mono-centric urban systems, with a clear dominance of their capital cities. Tallinn inhabited 30,6\% of the national population and was 4 times bigger than the second largest city in Estonia, and Riga inhabited 34,1\% of the population and was 7 times bigger than the second largest city in 1989 in Latvia. It is interesting to see, although not unexpected, that the trends in population redistribution were different between the Baltic States during the post-soviet transition period. While the proportion of the total country population remained almost unchanged in Tallinn (30,4\%), and Riga (34,0\%), it increased in the city of Vilnius (17,2\%) during 1989-2011. Moreover, the gap in population size between the largest cities declined in Latvia and Estonia, but increased in Lithuania. These figures illustrate that the urban system of Lithuania is evolving into a model where the capital city region is dominating, which is typical to the other Baltic States. Under the communist regime without market competition, and in a society with no significant economic and social differences, the Soviet territorial organization of Lithuania performed relatively well and was perceived as an achievement of Soviet urban planners (Vanagas et al., 2002). However, the transition to a market led neo-liberal economy, strengthening domestic and international competition, processes of globalization, social segregation, and other effects raised a lot of challenges for the inherited territorial organization in Lithuania. This is confirmed by very high rates of international and internal migration, shrinkage of rural areas, intense suburbanization of major cities and by other urban processes.

The empirical part of this paper will shed more light on how the socio-economic and political transformations have impacted the geography of population change in Lithuania. The study will show what are the winners and losers among regions and what are the main causes of these differences.

\section{DATA AND METHODS}

This study uses aggregated data on the low spatial level of seniūnija (corresponding to LAU2 level) from the 2001 and 2011 Lithuanian Censuses. There were 549 of such administrativestatistical units in Lithuania in 2011. Because over time the spatial borders of some seniūnija changed, and because we wanted to clearly distinguish urban and rural areas, we had to make some minor adjustments. After these adjustments we ended up with 547 spatial units covering Lithuania: 82 of them are classified as urban areas, and the rest is classified as rural areas. The average size of rural seniūnija is $135 \mathrm{~km}^{2}$, with approximately 2820 inhabitants in 2001 and 2470 inhabitants in 2011. The average size of the urban seniūnija is $17,4 \mathrm{~km}^{2}$, with 26,300 inhabitants in 2001 and 20,360 inhabitants in 2011. Since not all of the required data are provided by the 2001 and 2011 Censuses, we also used other sources, such as Agricultural Census data from 2003 and 2010 and data from Statistics Lithuania. We used some socioeconomic area characteristics which were only available at the level of the 60 Lithuanian municipalities.

In the descriptive part of the results we analysed the spatial pattern of population change between 2001 and 2011 in Lithuania. Next we used linear regression to model population change and to explore the relationship between the rate of the population change (dependent variable) and various territorial characteristics (independent variables). By using linear regression we were able to test the predictive power of a set of variables and to assess the relative contribution of each variable on the process of population change (Pallant, 2011). Based on a simple regression model with only locational characteristics we constructed further models in order to find out the underlying explanations for the geographical pattern of 
population change. The following models contained variables measuring socio-demographic and socio-economic characteristics. We used data from 2001/2003 as the baseline characteristics. We also included a variable measuring change in employment in the primary sector between 2001-2011, and a variable measuring the sum of foreign investments in the period between 2001-2011 (other variables regarding foreign investments were not significant in the models). Not all variables considered were reported in the main regression models because in the pre-selection process it was found that their influence was negligible. The variables we used can be categorised into locational, socio-demographic and socio-economic characteristics. We used this distinction in our models. We presented the results of the regression models in tables as well as in maps in which we show the Unstandardized Predictive values (values that the regression model predicts for the dependent variable when a certain set of independent variables is included) and Residuals (the actual value of the dependent variable minus the value predicted by the regression model).

The locational characteristics require some additional explanation. We started using a simple urban-rural distinction to replicate the existing spatial pattern of population change. By using this variable we aimed to examine how well spatial variation in population change can be explained by a urban-rural distinction. Using dummies we coded all the spatial units into one of the following categories: (1) three largest cities; (2) area within $15 \mathrm{~km}$ distance from one of the three largest cities; (3) other cities; (4) area within $15 \mathrm{~km}$ distance from a medium city (County capital); (5) area within $15 \mathrm{~km}$ distance from a smaller city (Municipal capital); reference category - the remaining areas or areas further than $15 \mathrm{~km}$ from the cities. During the initial analysis of the data we observed that the medium and smaller cities had the same rates of population change (decline), and to limit the number of variables included we grouped them into the same category. The areas around medium and smaller cities, however, varied in terms of population change. Detailed variable summary statistics for all included variables can be found in Table 1.

Table 1. Variable summary statistics - 2001 and 2011 Lithuanian Census data and Statistics Lithuania $(N=547)$.

\begin{tabular}{|c|c|c|c|c|}
\hline & Minimum & Maximum & Mean & $\begin{array}{c}\text { Std. } \\
\text { Deviation }\end{array}$ \\
\hline Percentage population change, 2001-2011 & -41.70 & 90.90 & -13.979 & 14.117 \\
\hline \multicolumn{5}{|l|}{ Urban - rural distinction $^{\mathrm{a}}$} \\
\hline 3 largest cities ${ }^{\mathrm{b}}$ & 0 & 1 & 0.06 & 0.235 \\
\hline Areas within $15 \mathrm{~km}$ from 3 largest cities & 0 & 1 & 0.11 & 0.308 \\
\hline Other cities & 0 & 1 & 0.09 & 0.288 \\
\hline Areas within $15 \mathrm{~km}$ from medium cities & 0 & 1 & 0.09 & 0.288 \\
\hline Areas within $15 \mathrm{~km}$ from smaller cities & 0 & 1 & 0.32 & 0.465 \\
\hline \multicolumn{5}{|l|}{ Seniūnija-level variables } \\
\hline Percentage working-age (15-64) population, 2001 & 47.80 & 83.00 & 61.318 & 4.896 \\
\hline Percentage households with children, 2001 & 13.79 & 54.56 & 36.296 & 6.845 \\
\hline Percentage Lithuanian ethnic group, 2001 & 2.30 & 100.00 & 87.149 & 23.639 \\
\hline Percentage joblessness, 2001 & 1.65 & 24.73 & 8.781 & 3.548 \\
\hline $\begin{array}{l}\text { Percentage of employment in primary sector } \\
\text { (agriculture), } 2003^{\mathrm{c}}\end{array}$ & .00 & 41.78 & 16.275 & 9.592 \\
\hline $\begin{array}{l}\text { Change in the percentage of employment in } \\
\text { primary (agriculture) sector, 2003-2010 }\end{array}$ & -27.57 & 16.85 & -2.959 & 5.584 \\
\hline \multicolumn{5}{|l|}{ Municipal-level variables } \\
\hline Average wage, 2001 & 676 & 1686 & 826.71 & 173.608 \\
\hline Percentage university education, 2001 & 17.18 & 38.38 & 23.473 & 4.577 \\
\hline Percentage employees in industry sector, 2001 & 8.50 & 55.50 & 25.559 & 8.698 \\
\hline
\end{tabular}




\begin{tabular}{|c|c|c|c|c|}
\hline Percentage employees in commercial sector, 2001 & 7.70 & 43.70 & 21.673 & 6.687 \\
\hline $\begin{array}{l}\text { Foreign investments, per capita (EURm ), Sum } \\
\text { 2001-2011 }\end{array}$ & 0.01 & 126.56 & 9.3022 & 23.082 \\
\hline Number of social dwellings per 1000 person, $2003^{\mathrm{d}}$ & 0.17 & 35.62 & 2.1328 & 1.8753 \\
\hline
\end{tabular}

\section{DESCRIPTIVE RESULTS OF POPULATION DECLINE IN LITHUANIA}

According to the Censuses, in the period between 1989 and 2011 Lithuania lost 17,2\% of its population. The actual loss could be even higher, because a lot of emigrants do not register when they leave the country (Civinskas et al. 2011). The population decline was almost three times more intense during the second decade of the post-socialist transition period compared to the first decade. The spatial pattern of population change between 2001 and 2011 is illustrated in Figure 1. The map shows that the range of the population change varies a lot across Lithuania, with some areas almost doubling their population $(+91 \%)$, while other areas lost close to half of their population (-41\%) during the same period. The map clearly shows that the population decreased almost everywhere, except in the areas around the largest cities, where metropolitan growth through suburbanization is taking place since the early 1990s. The sharpest decline in population can be observed in rural areas located further from the cities. $41 \%$ of the country's area (in $\mathrm{km}^{2}$ ) lost more than $20 \%$ of the population during the last decade and only $6 \%$ of the country's area did not experience a drop in population. The main reason of population decline in Lithuania was emigration, which accounted for $80-90 \%$ of the population loss (Civinskas et al., 2011; Statistics Lithuania, 2012). On the other hand, natural decrease was also high and the total fertility rate in Lithuania is now amongst the lowest in Europe. The causes of decline vary within the country. Negative natural change is an important factor of population decline in the eastern part of Lithuania, while out-migration was most important in the western part of the country (Kuliešis and Pareigiené, 2011).

If we want to understand the population change as we see it in the map in Figure 1, we need to look at the underlying factors. The geographical pattern of population change suggests that certain territorial characteristics have a strong effect on the variation in population change throughout the country. Based on the map we expect that locational factors, which we summarise in an urban-rural classification, will be one of the most important factors in explaining population change, even after controlling for other area characteristics. The distance from major cities also seems to play an important role: areas near larger cities experience population growth and areas further away from cities generally experience a strong decrease in population. Underlying the spatial pattern are also socio-demographic and economic characteristics. Population decline is likely to be highest in those regions with a low percentage of working-age population, a low percentage of households with children, and high levels of unemployment. The spatial pattern of population decline can also be expected to be influenced by the educational level of the working age population and structure of the labour market. Population is likely to increase in areas with higher share of higher educated people, and in areas with increasing employment in the service sector, but will decrease in areas with a high percentage of employment in the primary sector (agriculture). In addition, we expect that those areas which receive the highest levels of foreign investments will show a lower decrease in a population. 




Figure 1. Population change in seniūnija in 2001-2011 (Source: own calculations based on the 2001 and 2011 Lithuanian Census).

\section{MODELLING POPULATION CHANGE IN LITHUANIA}

In order to better understand the causes of the existing spatial pattern of population change, we employed linear regression to model the effect of different territorial characteristics on population change at the level of seniūnija. Table 2 shows the results of six models of population change. In model 1 we only included an urban-rural classification, with rural areas as the reference category. This simple model already explains $44 \%$ of all variation. The results show that the territories around the largest cities are the only areas gaining population. Although, the three largest cities themselves are actually losing population, the average rate of this decline is slower than in the other places. The areas around medium sized cities stand out by the smaller population drop compared to the cities they surround, while the areas around smaller cities show a higher level of population decline. The predicted values of model 1 are mapped in Figure 2. Comparison of this map with the map in Figure 1 shows how well the model performs. The modelled spatial pattern shows that the urban-rural distinction, city size, and distance to cities are major explanatory factors of population decline. 
Table 2. Linear regression model of percentage population change at the seniūnija level $(N=548)$.

\begin{tabular}{|c|c|c|c|c|c|c|c|c|c|c|c|c|}
\hline & \multicolumn{2}{|c|}{ Model 1} & \multicolumn{2}{|c|}{ Model 2} & \multicolumn{2}{|c|}{ Model 3} & \multicolumn{2}{|c|}{ Model 4} & \multicolumn{2}{|l|}{ Model 5} & \multicolumn{2}{|l|}{ Model 6} \\
\hline & $B$ & $\beta$ & $B$ & $\beta$ & $B$ & $\beta$ & $B$ & $\beta$ & $B$ & $\beta$ & $B$ & $\beta$ \\
\hline \multicolumn{13}{|l|}{$\begin{array}{l}\text { Locational characteristics (ref = } \\
\text { rural areas) }\end{array}$} \\
\hline 3 largest cities & 13.540 & $0.225^{* * *}$ & 5.662 & $0.094^{* *}$ & 9.393 & $0.156^{* * *}$ & 9.303 & $0.155^{* * *}$ & 6.633 & $0.110^{* *}$ & 4.034 & 0.067 \\
\hline $\begin{array}{l}\text { areas within } 15 \mathrm{~km} \text { from } 3 \text { largest } \\
\text { cities }\end{array}$ & 31.617 & $0.690 * * *$ & 26.914 & $0.588^{* * *}$ & 26.377 & $0.576^{* * *}$ & 26.349 & $0.575^{* * *}$ & 24.456 & $0.534^{* * *}$ & 24.374 & $0.532 * * *$ \\
\hline other cities & 5.999 & $0.123 * * *$ & 0.453 & 0.009 & 0.624 & 0.013 & 0.606 & 0.012 & -2.049 & -0.042 & -2.019 & -0.041 \\
\hline $\begin{array}{l}\text { areas within } 15 \mathrm{~km} \text { from } \\
\text { medium cities }\end{array}$ & 9.479 & $0.188 * * *$ & 7.416 & $0.147 * * *$ & 7.166 & $0.142 * * *$ & 7.166 & $0.142 * * *$ & 6.603 & $0.131 * * *$ & 6.143 & $0.122 * * *$ \\
\hline $\begin{array}{l}\text { areas within } 15 \mathrm{~km} \text { from smaller } \\
\text { cities }\end{array}$ & 3.885 & $0.128 * * *$ & 2.877 & $0.095^{* *}$ & 2.344 & $0.077^{* *}$ & 2.360 & $0.078^{* *}$ & 1.896 & $0.063 *$ & 2.015 & $0.066^{*}$ \\
\hline \multicolumn{13}{|l|}{ Socio-demographic characteristics } \\
\hline $\begin{array}{l}\text { Percentage working-age } \\
\text { population, } 2001\end{array}$ & & & 0.640 & $0.222 * * *$ & 0.221 & 0.077 & 0.227 & 0.079 & 0.134 & 0.046 & 0.127 & 0.044 \\
\hline $\begin{array}{l}\text { Percentage households with } \\
\text { children, } 2001\end{array}$ & & & & & 0.409 & $0.198 * * *$ & 0.409 & $0.198 * * *$ & 0.371 & $0.180^{* * *}$ & 0.360 & $0.175^{* * *}$ \\
\hline \multicolumn{13}{|l|}{ Socio-economic characteristics } \\
\hline Percentage joblessness, 2001 & & & & & & & -0.027 & -0.007 & -0.115 & -0.029 & -0.120 & -0.030 \\
\hline $\begin{array}{l}\text { Percentage of employment in } \\
\text { primary sector, } 2003\end{array}$ & & & & & & & & & -0.243 & $-0.165 * * *$ & -0.245 & $-0.166^{* * *}$ \\
\hline $\begin{array}{l}\text { Change in the percentage of } \\
\text { employment in primary sector, } \\
\text { 2003-2010 }\end{array}$ & & & & & & & & & -0.434 & $-0.172 * * *$ & -0.424 & $-0.168 * * *$ \\
\hline $\begin{array}{l}\text { Foreign investments, per capita } \\
\text { 2001-2011 }\end{array}$ & & & & & & & & & & & 0.046 & $0.075 * *$ \\
\hline Constant & -20.715 & & -57.998 & & -47.120 & & -47.282 & & -35.904 & & -35.260 & \\
\hline$R^{2}$ & 0.438 & & 0.459 & & 0.481 & & 0.481 & & 0.503 & & 0.506 & \\
\hline $\mathrm{F}(\mathrm{df})$, significance & $\begin{array}{l}541(5) \\
0.000\end{array}$ & & $\begin{array}{l}540(6) \\
0.000\end{array}$ & & $\begin{array}{l}539(7) \\
0.000\end{array}$ & & $\begin{array}{l}538(8) \\
0.000\end{array}$ & & $\begin{array}{c}536(10), \\
0.000\end{array}$ & & $\begin{array}{l}535(11) \\
0.000\end{array}$ & \\
\hline $\begin{array}{l}\text { Residual sum of squares (total } 108 \\
\text { 810) } \\
* \mathrm{p}<0.10 ; * * \mathrm{p}<0.05 ; * * * \mathrm{p}< \\
0.01 \text {. }\end{array}$ & 61152 & & 58866 & & 56438 & & 56433 & & 54083 & & 53702 & \\
\hline
\end{tabular}




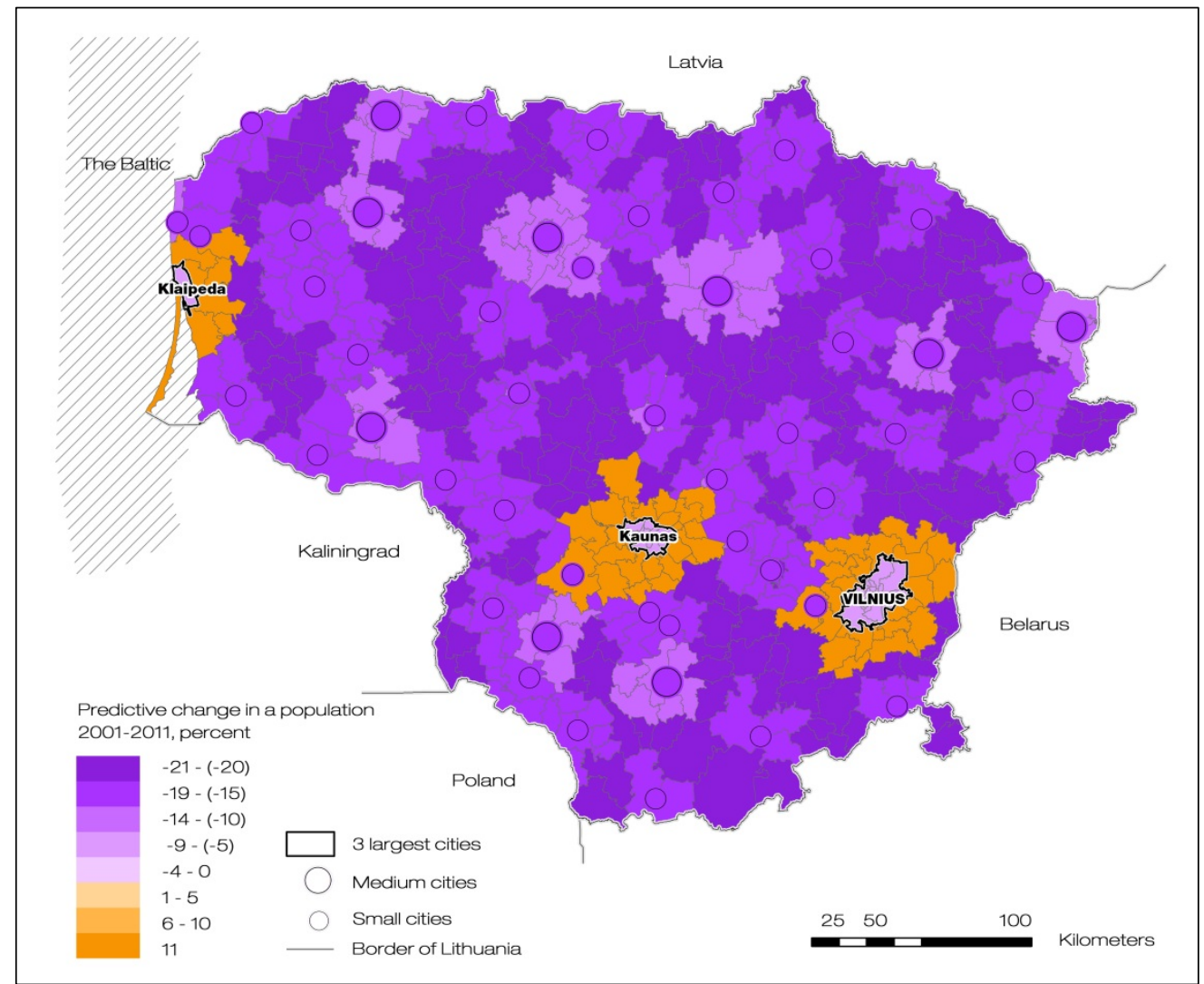

Figure 2. Predictive population change according to geographical location factor in seniūnija in 2001-2011 (based on the outcome of model 1) (Source: own calculations based on the 2001 and 2011 Lithuanian Census).

In the subsequent models we sought to examine whether the geography of population decline can be explained by other factors: what are the underlying explanations of the geographical pattern? In model 2 a socio-demographic variable measuring the percentage of working-age population (people aged between 15 and 65) is included. This age group has the highest impact on the population change compared to the other groups (the under 15 and over 65 year old, results not shown). The higher the percentage of working-age population, the higher the increase in population. Part of this effect is caused by the fact that a large proportion of the working age population are also in the family formation stage. After controlling for the working age population, the effect of the three largest cities decreases significantly. This means that the relatively favourable population trajectory of these cities is caused by their favourable age composition. According to Census data from 2001, in the three largest cities $70.6 \%$ of the population was of working age, compared with $61.3 \%$ in Lithuania as a whole, and $58.3 \%$ in rural areas. Because of the inclusion of the age composition variable, the effect of the other cities, compared to the reference category of rural areas, diminishes and becomes insignificant in model 2. Thus, when controlling for the age composition, other cities are not statistically different in population change from the rural areas. The effect of suburban areas reduced only slightly after the age-composition was included, which suggests that the geographical location of suburban areas is more important than their demographic composition.

Model 3 also includes the percentage of households with children. The higher the percentage of the households with children, the higher the increase in population (or the lower the decrease). This variable partly overlaps with the working age population (the correlation is 0.579 , so multicollinearity is no big issue), therefore the effect of the working age population 
decreases when the percentage of households with children is included. Model 3 explains almost $48 \%$ of all variation in population change between the areas. Model 4 also includes a variable indicating the percentage of joblessness. An interesting and unexpected finding is that the level of unemployment has no significant effect on the population change in an area ${ }^{4}$. The correlation between population change and unemployment rate was also insignificant in our dataset. An underlying cause might be that unemployment is poorly registered. Many people in Lithuania register themselves as unemployed in order to receive a social benefit, while at the same time they might be working informally. Model 5 includes a variable measuring the percentage of employment in the primary sector (agriculture), and a variable measuring the change in the percentage of employment in the primary sector between 2003 and 2010. The results show that the higher the percentage of employment in the primary sector, the higher the population decline in an area. The results also show that a decrease in the percentage of employment in the primary sector is associated with an increase in population.

Finally, in model 6 we included a variable measuring the level of foreign investments in the period of 2001-2011. The results show that the higher the level of foreign investments, the lower the population drop. After controlling for this variable the effect of the largest three cities became insignificant. Therefore, the positive effect of the largest cities, in addition to the favourable age structure, can also be explained by the higher levels of foreign investments. Meantime, the effect of the other cities and the suburban areas (no matter what is the size of the city they surround) remained almost the same after controlling for investments. This result implies that the investments have little impact on the population change in these areas. In model 6 only the effect of the suburban areas (around the largest and medium cities) remained significant. The effect of these areas does not vary a lot throughout the process of modelling, suggesting that the geographical location factor, combined with the process of suburbanisation, is very important in explaining the population change in these areas.

Model 6 explains nearly 51\% of all variation in the data, with a limited set of territorial characteristics. This is a good result, especially since the size of the spatial units is relatively large and there is little homogeneity within them. Other studies, which used linear regression to model similar social processes, found similar levels of prediction (Chi and Voss, 2011; van Ham and Clark, 2009). When we map the predicted values of model 6 (see Figure 3 ) we see that the model performs really well and replicates the pattern of real population change as observed in Figure 1. Interestingly, the model which only included locational factors already explained $44 \%$ of all variation between the areas, while a model which only included socio-demographic and economic characteristics explains only $27 \%$ of all variation (see Table 3 in the Appendix). When we map the predicted values of a map without locational characteristics (Figure 4 in the Appendix) we do see the effects of cities and the surrounding areas, but such model fails to identify the positive population change in the suburban areas of the larger cities. This indicates that these suburban areas have a certain 'locational advantage' over other places with regard to how attractive they are to live in. So geography, and mainly distance to the three main cities, plays a role on top of socio-demographic and economic area characteristics. This relates back to the on-going transformations of the urban network (mainly metropolitan growth) as discussed in the theoretical part of this paper.

\footnotetext{
${ }^{4}$ We decided to include this variable into the main model in spite of the fact that it does not contribute significantly to the regression. According to many studies an unemployment rate is a relevant factor determining out-migration and population decline (e.g., Ní Laoire, 2000; Panagopoulos and Barreira 2012; Stockdale, 2004).
} 


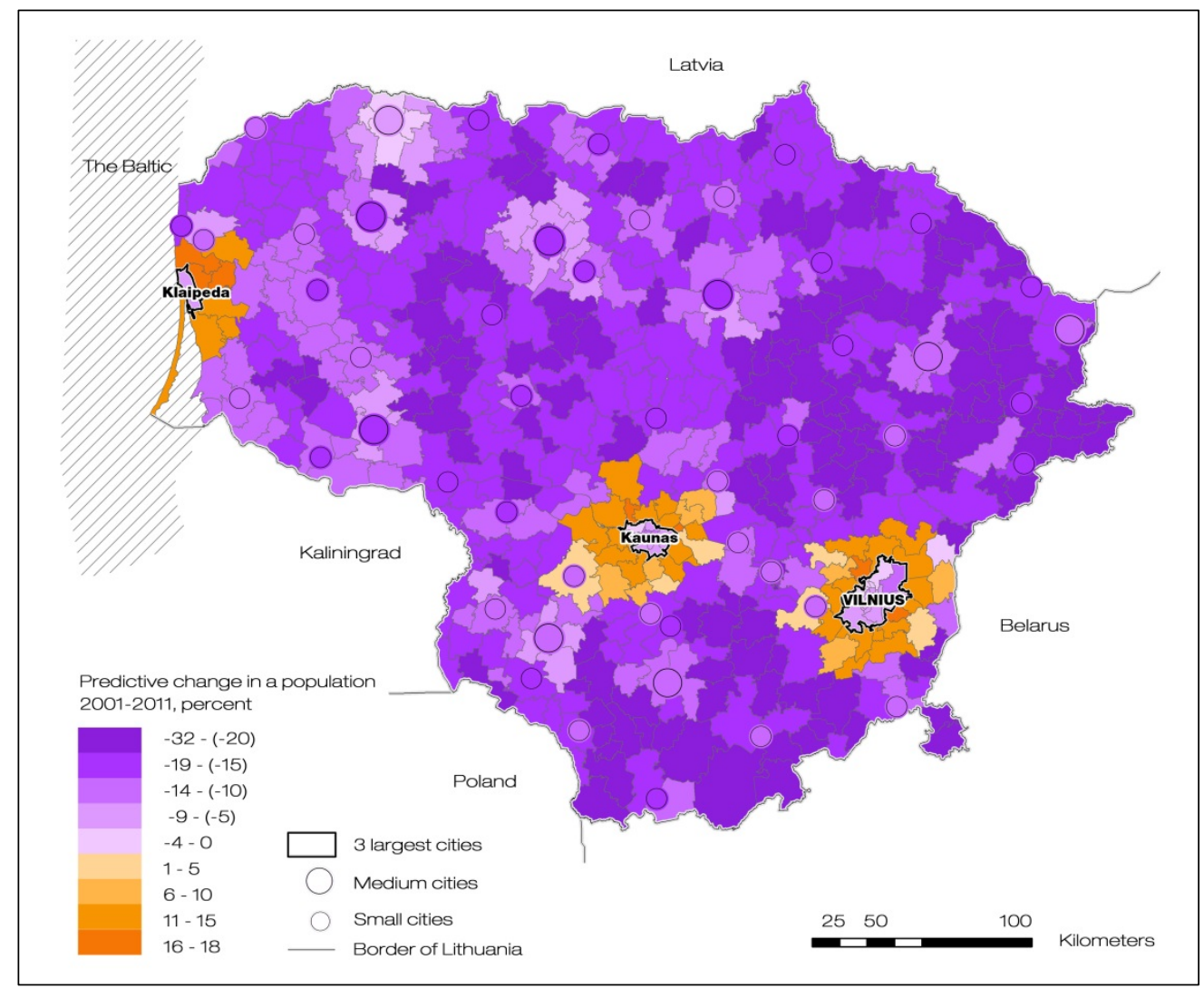

Figure 3. Predictive population change according to geographical location and socioeconomic factors in seniūnija in 2001-2011 (based on the outcome of model 6) (Source: own calculations based on the 2001 and 2011 Lithuanian Census).

The results of the cartographical analysis showed that all predictive models are less accurate in the areas where the actual population change was the most extreme. How well the models performed can be illustrated by mapping the residual values of each model (see Figure 5 in the Appendix). The mapped residuals show that the models performed less well in the suburban areas around the largest cities (and even the smaller cities), which experienced population increase. Although the final model (Model 6) which included all locational and socio-economic characteristics, performs much better than the model with only locational factors, also this model overestimates population change in the suburban areas. Interestingly, the model which included only social and economic characteristics mostly underestimates change in the same suburban areas. This finding suggests that there might be more factors influencing population change in the suburbs, which we could not include in our models, or that these areas are less homogenous and therefore less predictable.

Many other variables were included in the preliminary analysis, but they were excluded from the final models as presented since they did not improve the predictive power of the models. We have tested models with more detailed information on labour market structure, average wages, educational level, the number of economic entities and public housing (these variables were only available at the municipal level due to limited access to the lower level data). However, none of these variables were significant in the models. The extended model, including all characteristics, can be found in Table 4 in the Appendix. 


\section{CONCLUSIONS AND DISCUSSION}

Lithuania is losing population at increasing rates since the political reforms of the early Nineteen Nineties, and it is now among the fastest shrinking countries in the world. Our analyses showed that the population decline is unevenly distributed throughout the country. The highest rates of depopulation were recorded for the rural and peripheral areas of Lithuania; meanwhile population increases could be observed in the regions directly surrounding the major cities. Although all CEE countries experienced similar trends of spatial development, the urban structure developed during the Soviet times, makes the spatial variations in population change more profound in Lithuania compared to the other countries. The main reason was that the largest cities in Lithuania were relatively underdeveloped as they lagged behind in their 'natural' growth.

The main aim of this paper was to get more insight into the geography of population change in Lithuania and to increase our understanding of the factors which contribute to population change. A novelty of the study was that we investigated shrinkage for a whole country, using data at a very low spatial level (seniūnija), where most other studies use much larger municipalities. Moreover, this is one of the first studies to use the 2011 Lithuanian Census. In our linear regression models we included two types of area characteristics: a detailed urban-rural classification, and a range of socio-demographic and economic characteristics. Our main hypothesis was that the urban-rural distinction would be the most important predictor of variation in population change between regions.

Our results show that the geographical pattern of population decline is highly structured and that city size and distance to cities are important factors in explaining this pattern. The model with only the locational factors included already explained $44 \%$ of all variation in population change between areas. Thus the hypothesis that the geographical location is an important predictor of the population change can be supported. In line with the literature, we found that the age-structure and the household structure (percentage of households with children) of the population are important socio-demographic characteristics playing a role in the process of decline. The higher the percentage of working-age population and households with children, the lower we found population decline to be. An interesting and unexpected finding is that the percentage of joblessness has no significant impact on population change. This is contrary to what was found by others for other countries. Our results also showed that the higher the percentage of employment in the agricultural sector, the higher the population decline. It is likely that this factor will lose its significance in the next decade as the effect of Soviet policies which prioritized agricultural development will disappear as population has redistricted to cities. We did not find a significant relationship between jobs in other sectors of the economy (commercial, industry, construction) and the population decline. Moreover, the analysis showed that those areas receiving higher levels of foreign investments are more likely to experience an increase in population. Our final regression model explained nearly 51\% of all variation in the data. Our analysis of predicted values and associated residuals showed that our models performed less well in the areas directly surrounding the larger cities. This suggests that there are processes at play that could not be captured using the variables we included.

To conclude, the geographical pattern of population change clearly shows that the areas directly surrounding larger cities are increasing in population, while rural and peripheral areas are experiencing extreme population decline. Our results give little hope to those who would like to develop policies to stop this decline outside metropolitan regions. Geography seems to be more important than socio-demographic and economic area characteristics. Lithuania can be seen as a large experiment of urban development and population redistribution. Under Soviet rule and a centrally planned economy, policies were aimed at 
actively redistributing population away from the largest cities and towards regional cities and rural areas. This policy was more explicit in Lithuania than in other CEE countries, and was aimed at reducing the dominance of the capital city of Vilnius. However, after the early 1990, and the fall of the Soviet regime, market economic forces took over and despite large scale emigration from Lithuania, the three largest urban regions started to grow. Most population growth was experienced in the suburban rings of these cities. This indicates that the preferences of households developed in the direction of the suburbs, a process which could be observed decades before in Western European cities.

\section{Acknowledgements}

We would like to thank the Lithuanian Education Exchanges Support Foundation (grant No. LLP-LdV-PLM-2012-LT-0742) for financial support through the Leonardo da Vinci programme initiated by European Union and to the Research Council of Lithuania for financial support of the PhDs' academic outing (grant No. DOC-14073). We would also like to thank the host institution, the Department OTB Research Institute for the Built Environment, Faculty of Architecture and the Built Environment, Delft University of Technology in the Netherlands, for its hospitality and for the facilities and office space supplied.

\section{REFERENCES}

Aberg M (2005) Baltic orientations: Globalization, regionalization, or “EU-izolation”? In: Hamilton FWI, Andrews KD and Pichler-Milanovic N (eds.) Transformation of Cities in Central and Eastern Europe - Towards Globalization. Tokyo: United Nations University Press, 399-427.

Abreu A (2012) The new economics of labor migration: beware of Neoclassicals bearing gifts. Forum for social economics 41(1): 46-67.

Arango J (2000) Explaining migration: a critical view. International Social Science Journal 52(165): 283-296.

Bater JH (1980) The Soviet City. London: Edward Arnold.

Beauregard RA (2013) Shrinking cities in the United States in historical perspective: A research note. In: Pallagst $\mathrm{K}$, Wiechmann $\mathrm{T}$ and Martinez-Fernandez $\mathrm{C}$ (eds.) Shrinking Cities: International Perspectives and Policy Implications. New York: Routledge, 61-68.

Bertaud A and Renaud B (1997) Socialist cities without land markets. Journal of Urban Economics 41(1): 137-151.

Berzins A and Zvidrins P (2011) Depopulation in the Baltic States. Lithuanian Journal of Statistics 50(1): 39-48.

Blau PM and Duncan OD (1967) The American occupational structure. New York, London, Sydney: John Wiley \& Sons, Inc.

Borén T and Gentile M (2007) Metropolitan processes in post-communist states: An introduction. Geografiska Annaler, Series B Human Geography 89(2): 95-110.

Boyle P, Halfacree K and Robinson V (1998) Exploring contemporary migration. New York: Addison Wesley Longman.

Burholt V and Dobbs C (2012) Research on rural ageing: Where have we got to and where are we going in Europe? Journal of Rural Studies 28(4): 432-446.

Cawley ME (1994) Desertification: Measuring population decline in rural Ireland. Journal of Rural Studies 10(4): 395-407. 
Cirtautas M (2013) Urban sprawl of major cities in the Baltic States. Architecture and Urban Planning 7: 72-79.

Civinskas R, Genys D, Kuzmickaite D, Tretjakova V (2011) The Dynamics of demographic decline and its consequences for Lithuania / Viewpoints from liberal perspective. In: Bruil C, van Schie P and van de Velde M (eds.) The dynamics of demographic decline. The Hague: Oranje/Van Loon, 105-115.

Collantes F, Pinilla V, Sáez LA, Silvestre J (2013) Reducing depopulation in rural Spain: The impact of immigration. Population, Space and Place (online version: Doi: 10.1002/psp.1797).

Eberstadt N (1994) Demographic shocks after communism: Eastern Germany, 1989-93. Population and Development Review 20(1): 137-152.

Enyedi G (1998) Transformation in Central European Postsocialist Cities. In: Enyedi G (ed.) Social Change and Urban Restructuring in Central Europe. Budapest: Akadémiai Kiadó, 109-136.

Favell A (2008) The new face of east-west migration in Europe. Journal of ethnic and migration studies 34(5): 701-716.

Gentile M, Tammaru T and van Kempen R (2012) Heteropolitanization: Social and spatial change in Central and East European Cities. Cities 29(5): 291-350.

Haartsen T and Venhorst V (2009) Planning for decline: anticipation on population decline in the Netherlands. Tijdschrift voor economische en sociale geografie 101(2): 218-227.

Haase A, Athanasopoulou A and Rink D (2013b) Urban shrinkage as an emerging concern for European policymaking. European Urban and Regional Studies (online version: Doi: 10.1177/0969776413481371).

Haase A, Bernt M, Großmann K, Mykhnenko V and Rink D (2013a) Varieties of shrinkage in European cities. European Urban and Regional Studies (online version: Doi: 10. 1177/0969776413481985).

Hoekveld JJ (2012) Time-space relations and the differences between shrinking regions. Built Environment 38(2): 179-195.

Hospers GJ (2012) Coping with shrinkage in Europe's cities and towns. Urban design international 18: 78-89.

Hudson R (2005) Rethinking change in old industrial regions: reflecting on the experiences of North East England. Environment and Planning A 37(4): 581-96.

Huzinec GA (1978) The impact of industrial decision-making upon the Soviet urban hierarchy. Urban Studies 15: 139-148.

Jamieson L (2000) Migration, place and class: youth in a rural area. The Sociological Review 48(2): 203-223.

Kahanec M, Zaiceva A and Zimmermann KF (2010) Lessons from migration after EU enlargement. In: Kahanec M and Zimmermann KF (eds.) EU labour markets after post-enlargement migration. Bonn: Springer, 3-45.

Kazlauskienė A and Rinkevičius L (2006) Lithuanian "brain drain” causes: Push and pull factors. Engineering economics 1(46): 27-37.

Kelo M and Wächter B (2006) Brain drain and brain gain / Migration in the European Union after enlargement. A study by the academic coopertaion association, The Hague.

Kroll F and Kabisch N (2012) The relation of diverging urban growth processes and demographic change along an urban-rural gradient. Population, Space and Place 18(3): $260-276$.

Krupickaitè D (2003) Naujos Lietuvos ir kitų Baltijos šalių miestų sistemų raidos tendencijos [New tendencies of town system development in Lithuania and other Baltic States]. Geografija 39(2): 38-44. 
Kuliešis G and Pareigienė L (2011) Lietuvos regionų depopuliacijos prielaidų tyrimas. [Study of the depopulation assumptions of the Lithuanian regions]. Management theory and studies for rural business and infrastructure development 5(29): 116-125.

Kupiszewski M, Durham, H and Rees P (1998) Internal migration and urban change in Poland. European Journal of Population 14(3): 265-290.

Leetmaa K and Tammaru T (2007) Suburbanization in Countries in Transition: Destinations of suburbanisers in the Tallinn metropolitan area. Geografiska Annaler, Series B Human Geography 89(2): 127-46.

Lewis WA (1954) Economic Development with Unlimited Supplies of Labour. The Manchester school 22(2): 139-191.

Martí-Henneberg J (2005) Empirical evidence of regional population concentration in Europe, 1870-2000. Population, Space and Place 11(4): 269-281.

Martinez-Fernandez C, Wu CT, Schatz LK, Taira N and Vargas-Hernández JG (2012) The Shrinking Mining City: Urban Dynamics and Contested Territory. International Journal of Urban and regional Research 36(2): 245-260.

Müller B and Siedentop S (2004) Growth and shrinkage in Germany - trends, perspectives and challenges for spatial planning and development. German Journal of Urban Studies 44: 14-32.

Musil J (1993) Changing urban systems in post-communist societies in Central Europe analysis and prediction. Urban Studies 30(6): 899-905.

Musil J (2005) City development in Central and Eastern Europe before 1990: Historical context and socialist legacies. In Hamilton FWI, Andrews KD and Pichler-Milanovic $\mathrm{N}$ (eds.) Transformation of Cities in Central and Eastern Europe - Towards Globalization. Tokyo: United Nations University Press: 22-43.

Myrdal G (1997) Economic theory and underdeveloped regions. London: Duckworth.

Ní Laoire C (2000) Conceptualising Irish rural youth migration: A biographical approach. International Journal of Population Geography 6(3): 229-243.

Niedomysl $\mathrm{T}$ (2008) Residential preferences for interregional migration in Sweden: demographic, socioeconomic, and geographical determinants. Environment and Planning A 40(5): 1109-1131.

Niedomysl $\mathrm{T}$ and Amcoff $\mathrm{J}$ (2011) Is there hidden potential for rural population growth in Sweden? Rural Sociology 76(2): 257-279.

Nuissl H and Rink D (2005) The 'product' of urban sprawl in eastern Germany as a phenomenon of post-socialist transformation. Cities 22(2): 123-34.

Pallant J (2011). SPSS survival manual. A step by step guide to data analysis using SPSS, 4th edition. Australia: Allen \& Unwin.

Panagopoulos T and Barreira AP (2012) Shrinkage perceptions and smart growth strategies for the municipalities of Portugal. Built Environment 38(2): 276-292.

Polèse M and Shearmur R (2006) Why some regions will decline: A Canadian case study with thoughts on local development strategies. Papers in Regional Science 85(1): 2346.

Rappaport J (2003) US urban decline and growth, 1950 to 2000. Federal Reserve Bank of Kansas City, Economic Review Third Quarter: 15-44.

Reckien D and Martinez-Fernandez C (2011) Why do cities shrink? European Planning Studies 19(8): 1375-1397.

Rumpel P, Slach O, Tichá I and Bedná P (2010) Urban Shrinkage in Ostrava, Czech Republic. Research report of Shrink Smart - The Governance of Shrinkage. Available at http://www.ufz.de/export/data/400/39016_WP2_report_Ostrava.pdf. Accessed 10 December 2013. 
Rychtaříková J (1999) Is Eastern Europe experiencing a second demographic transition? Acta Universitatis Carolinae - Geographica 34: 19-44.

Sailer-Fliege U (1999) Characteristics of post-socialist urban transformation in East central Europe. GeoJournal 49: 7-16

Schmidt S (2011) Sprawl without growth in Eastern Germany. Urban geography 32(1): 105128.

Šešelgis K (1996) Teritorijų planavimo raida Lietuvoje [Development of regional planning in Lithuania]. Urbanistika ir architektura 1(21): 4-19.

Sjaastad LA (1962) The costs and returns of human migration. Journal of Political Economy 70(5): 80-93.

Smith A. and Timár J (2010) Uneven transformations: Space, economy and society 20 years after the collapse of state socialism. European Urban and Regional Studies 17(2): 115-125.

Sobotka T, Zeman K and Kantorova V (2003) Demographic shifts in the Czech Republic after 1989: A second demographic transition view. European Journal of Population 19(3): 249-277.

Stark O and Bloom DE (1985) The new economics of labour migration. The American Economic Review 75(2): 173-178.

Statistics Lithuania (2012) Lithuanian 2011 Population Census in Brief, Vilnius: Statistics Lithuania.

Steinführer A and Haase A (2007) Demographic change as a future challenge for cities in East Central Europe. Geografiska Annaler, Series B Human Geography 89(2): 183-195.

Stockdale A (2004) Rural out-migration: Community consequences and individual migrant experiences. Sociologia Ruralis 44(2): 167-194.

Stryjakiewicz T, Ciesiółka P and Jaroszewska E (2012) Urban shrinkage and the post-socialist transformation: The case of Poland. Built Environment 38(2): 196-213.

Sýkora L (1999) Changes in the internal spatial structure of post-communist Prague. GeoJournal 49(1): 79-89.

Sýkora L and Čermák Z (1998) City growth and migration patterns in the context of 'communist' and 'transitory' periods in Prague's urban development. Space, Populations, Societies 16(3): 405-416.

Sýkora L and Ouředníček M (2007) Sprawling post-communist metropolis: Commercial and residential suburbanization in Prague and Brno, the Czech Republic. In: Razin E et al. (eds.) Employment Deconcentration in European Metropolitan Areas. Netherlands: Springer, 209-233.

Tammaru T (2001). Suburban Growth and Suburbanisation under Central Planning: The Case of Soviet Estonia. Urban Studies 38(8): 1341-1357.

Tammaru T and Sjöberg Ö (1999) On the move: explaining migration patterns in Estonia during the transition period. International Journal of Population Geography 5(4): 241260.

Thissen F, Droogleever J, Strijker D and Haartsen T (2010) Migration intentions of rural youth in the Westhoek, Flanders, Belgium and the Veenkoloniën, The Netherlands. Journal of Rural Studies 26(4): 428-236.

Ubarevičienè R, Burneika D and Kriaučiūnas E (2011) The sprawl of Vilnius city establishment and analysis of growing urban region. Annales Geographicae 43-44: 96107.

United Nations (2013) World Population Prospects: The 2012 Revision. CD-ROM Edition.

van Ham M and Clark WAV (2009) Neighbourhood mobility in context: household moves and changing neighbourhoods in the Netherlands. Environment and Planning A 41(6): 1442-1459. 
Vanagas J, Krišjane Z, Noorkoiv R and Staniūnas A (2002) Planning urban systems in Soviet times and in the era of transition: The case of Estonia, Latvia and Lithuania. Geographia Polonica 75(2): 75-100.

Walford NS and Kurek S (2008) A comparative analysis of population ageing in urban and rural areas of England and Wales, and Poland over the last three census intervals. Population, Space and Place 14(5): 365-386.

Westlund $\mathrm{H}$ and Pichler W (2012) The Swedish countryside in the neo-urban knowledge economy. Regional Science Policy \& Practice 5(2): 225-237.

Wiechmann T and Pallagst KM (2012) Urban shrinkage in Germany and the USA: A comparison of transformation patterns and local strategies. International Journal of Urban and Regional Research 36(2): 261-280. 


\section{APPENDIX}

Table 3. Linear regression model of percentage population change at the seniūnija level $(N=548)$.

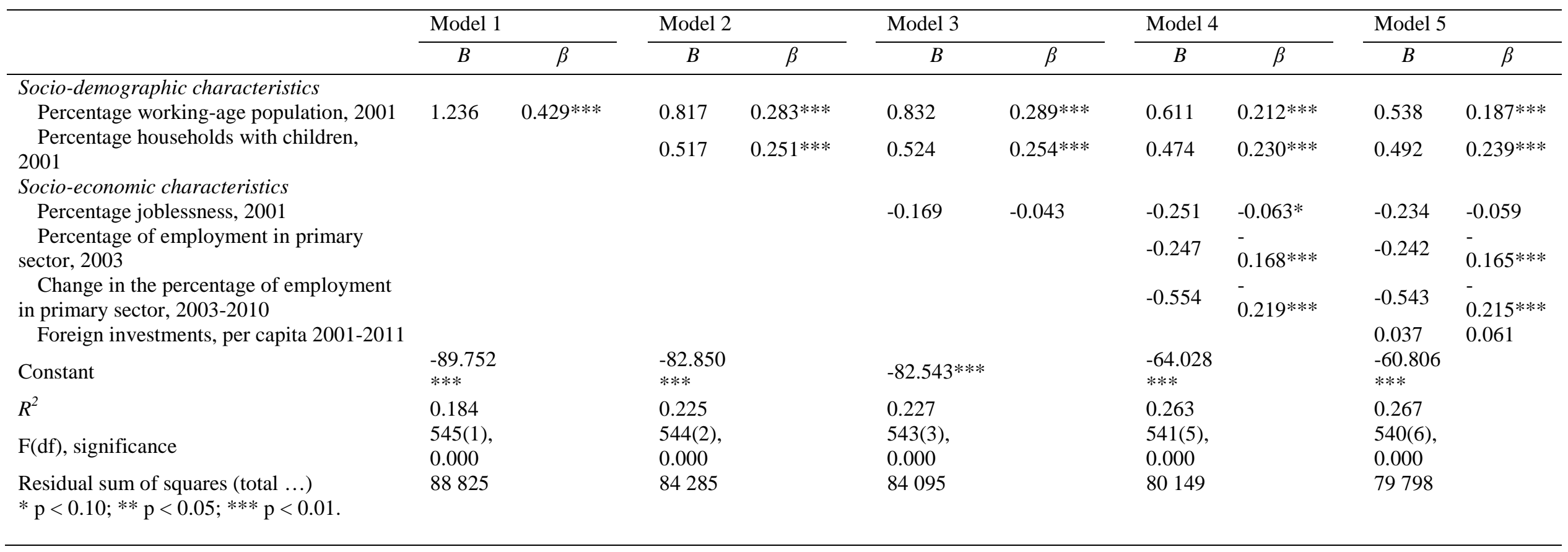

Table 4. Linear regression model of percentage population change at the seniūnija level $(N=548)$.

\begin{tabular}{|c|c|c|c|c|c|c|c|c|}
\hline & \multicolumn{2}{|c|}{ Model 1} & \multicolumn{2}{|c|}{ Model 2} & \multicolumn{2}{|c|}{ Model 3} & \multicolumn{2}{|c|}{ Model 4} \\
\hline & $B$ & $\beta$ & $B$ & $\beta$ & $B$ & $\beta$ & $B$ & $\beta$ \\
\hline \multicolumn{9}{|l|}{ Geographical characteristics (ref = rural areas) } \\
\hline 3 largest cities & 13.540 & $0.225^{* * *}$ & 4.034 & 0.067 & 2.730 & 0.029 & 0.507 & 0.008 \\
\hline areas within $15 \mathrm{~km}$ from 3 largest cities & 31.617 & $0.690 * * *$ & 24.374 & $0.532 * * *$ & 24.313 & $0.531 * * *$ & 23.674 & $0.517 * * *$ \\
\hline other cities & 5.999 & $0.123 * * *$ & -2.019 & -0.041 & -1.830 & -0.037 & -1.311 & -0.027 \\
\hline areas within $15 \mathrm{~km}$ from medium cities & 9.479 & $0.188 * * *$ & 6.143 & $0.122 * * *$ & 6.126 & $0.122 * * *$ & 6.458 & $0.128 * * *$ \\
\hline
\end{tabular}




\begin{tabular}{|c|c|c|c|c|c|c|c|}
\hline 3.885 & $0.128 * * *$ & 2.015 & $0.066^{*}$ & 2.072 & $0.068^{*}$ & 2.344 & $0.077^{*}$ \\
\hline & & 0.127 & 0.044 & 0.075 & 0.026 & 0.001 & 0.000 \\
\hline & & 0.360 & $0.175^{* * *}$ & 0.406 & $0.098 * * *$ & 0.439 & $0.213 * * *$ \\
\hline & & -0.120 & -0.030 & -0.117 & -0.030 & -0.157 & -0.040 \\
\hline & & -0.245 & $-0.166 * * *$ & -0.227 & $-0.154 * *$ & -0.220 & $-0.150 * *$ \\
\hline & & -0.424 & $-0.168 * * *$ & -0.395 & $-0.156 * * *$ & -0.411 & $-0.163^{* * *}$ \\
\hline & & 0.046 & $0.075^{* *}$ & 0.025 & 0.042 & 0.022 & 0.035 \\
\hline & & & & 0.171 & 0.055 & 0.267 & 0.087 \\
\hline & & & & 0.004 & 0.055 & 0.004 & 0.054 \\
\hline & & & & -0.000 & -0.003 & 0.001 & 0.010 \\
\hline & & & & -0.008 & 0.004 & 0.003 & 0.002 \\
\hline & & & & -0.059 & -0.032 & -0.053 & -0.029 \\
\hline & & & & -0.088 & -0.054 & -0.088 & -0.054 \\
\hline & & & & 0.037 & 0.026 & 0.031 & 0.021 \\
\hline & & & & -97.229 & -0.033 & -65.748 & -0.022 \\
\hline & & & & 69.368 & 0.021 & 55.765 & 0.017 \\
\hline & & & & & & -0.040 & -0.067 \\
\hline & & & & & & -41.371 & -0.005 \\
\hline-20.715 & & -35.260 & & -37.136 & & -33.055 & \\
\hline 0.438 & & 0.506 & & 0.511 & & 0.513 & \\
\hline 541(5), & & 535(11), & & 526(20), & & 524(22), & \\
\hline 0.000 & & 0.000 & & 0.000 & & 0.000 & \\
\hline 61152 & & 53702 & & 53131 & & 52815 & \\
\hline
\end{tabular}




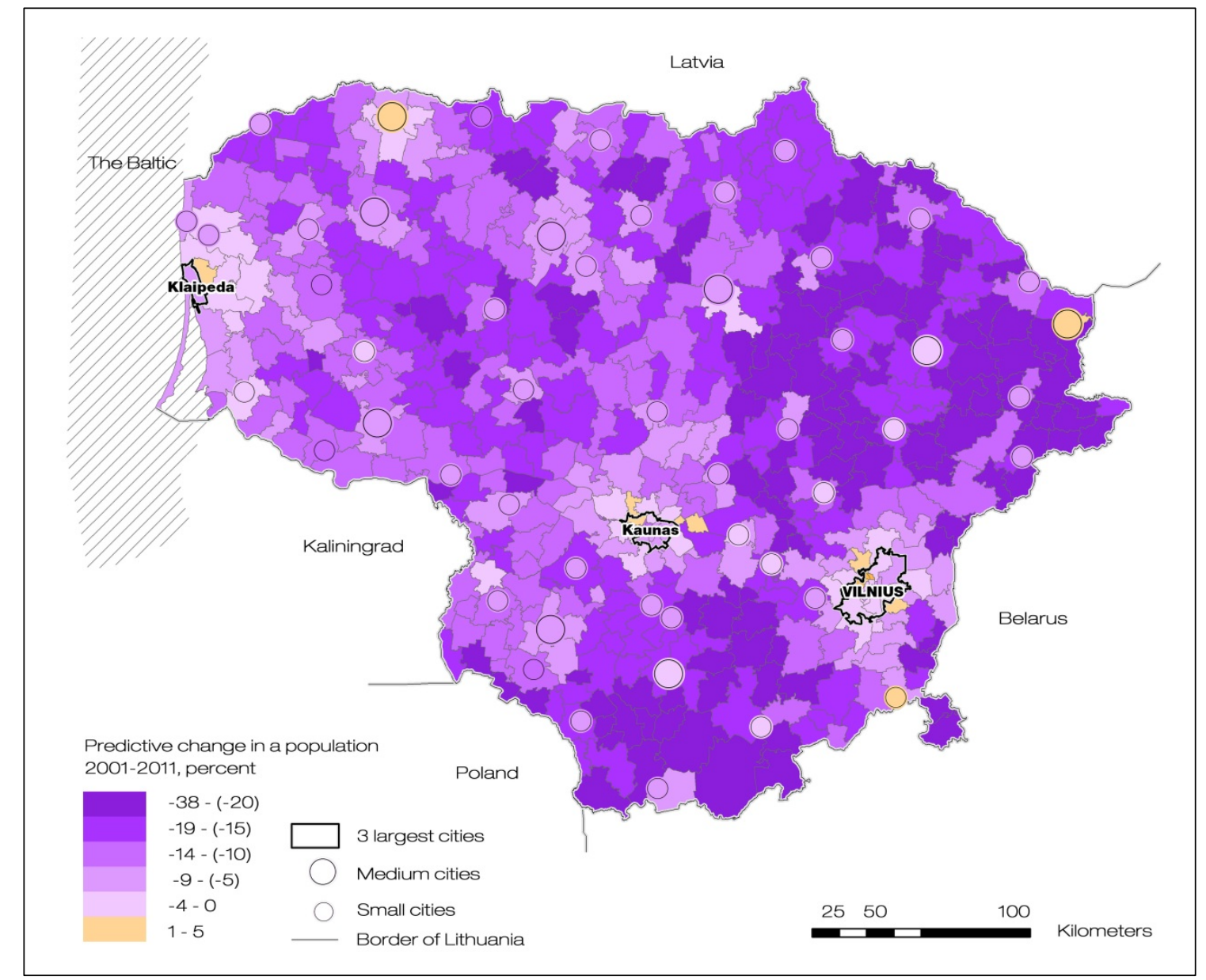

Figure 4. Predictive population change in seniūnija in 2001-2011 (based on model 4 in Table 3) (Source: own calculations based on the 2001 and 2011 Lithuanian Census). 




Figure 5. Residuals of various models (Source: own calculations based on the 2001 and 2011 Lithuanian Census). 